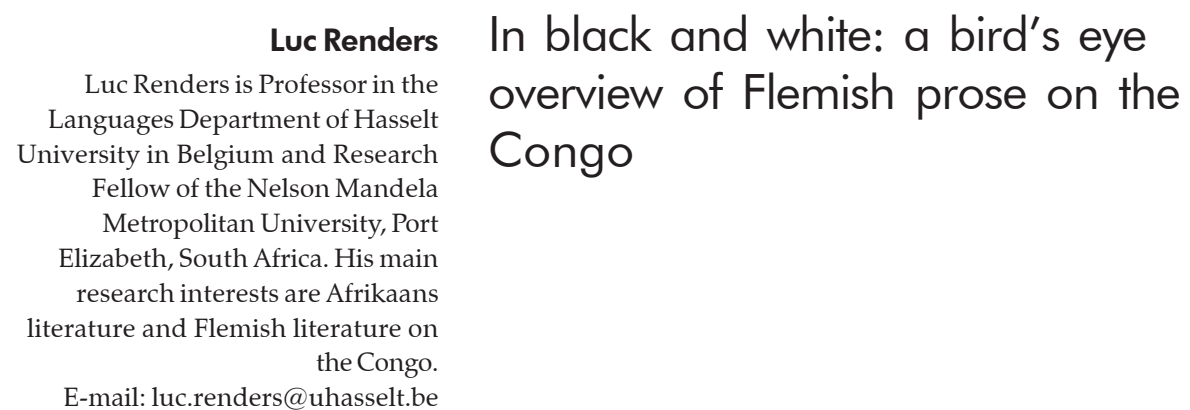

\title{
In black and white: a bird's eye overview of Flemish prose on the Congo
}

This article provides an overview of the literary prose written in Dutch about the Congo, the former Belgian colony. The Congo was ruled over by king Leopold II as his private property from 1885 to 1908. From 1908 to 1960 it was governed by the Belgian state. The Congo gained its independence on 30 June 1960. During the colonial period and after the Congolese independence a substantial number of Flemish literary works have been written about the Congo. During the colonial period most of them were written in the colonialist vein. They reflect a Eurocentric perspective and a colonialist attitude. However, there are also a number of writers who are critical of the colonial project. Some of them criticize the way in which the colonization is carried out; others reject the colonial enterprise out of hand. After the Congolese independence Flemish authors engaged in some serious soul searching. The universality of western values is examined and the problems regarding acculturation are addressed. In the last two decades authors such as Guido Tireliren and Lieve Joris have tried to understand the Congo from within. Most Flemish literature on the Congo is not of a high literary quality but from a historical-cultural perspective it is a very important domain of study. Key words: Flemish prose on the Congo, Congo literature, postcolonialism, Eurocentrism.

\section{A bird's eye historical overview}

The kingdom of Belgium was only established as an independent state in 1830. The first Belgian king, Leopold I, had imperial ambitions. However, he did not succeed in realizing them. His son and successor, Leopold II, followed in his father's footsteps with even greater determination and tenacity. After a number of failed attempts to acquire a colony in the Far East, Leopold II shifted his focus to Africa. The organisation of an international geographical conference in 1876 in Brussels had to provide a cover for his imperialistic ambitions. The topics for discussion at the conference were: "[...] the suppression of the slave trade in Central Africa, the extension of scientific knowledge about the area, and the bringing of civilization to the peoples living there" (Foeken 1985: 19-20). ${ }^{1}$ The conference decided on setting up the International Africa Association, split up into a number of National Committees.

The Belgian National Committee became the vehicle of king Leopold II's colonial campaign. In 1878 Henry Morton Stanley accepted the mission to establish a number of settlements along the Congo River. At the Conference of Berlin in 1885, organized 
to divide the African spoils amongst the European nations, the Congo became the fiefdom of Leopold II. The Congo Free State was born. The colonization of the overseas territory started without delay. In the first years of the $20^{\text {th }}$ century the inhuman treatment of the Congolese population was revealed, mainly through the sustained campaign of Edmund Dene Morel, a British activist, and Roger Casement, the British consul in the Congo. As a result in 1908 Leopold II was forced to relinquish control over his private kingdom on the equator.

Under Belgian stewardship the ruthless exploitation of the Congo was continued, but without the brutal excesses which characterised king Leopold II's reign of terror. State, Church and Industry complemented one another.

A substantial number of the Belgians who left for the Congo were Flemings. They lived and worked in a colony where the official language was French. A number of them wrote about their exotic experiences. After some initial reticence the home front was converted to the colonial cause. In Belgium the enthusiasm for the civilization and Christianization project in the Congo was widespread and overwhelming. At the different World Exhibitions, which took place in Belgium from the late $19^{\text {th }}$ century onwards, the Congo was given pride of place. Besides the crowd pulling ethnographical section - usually in the form of a live re-enactment of Congolese village life - the spotlight was on the economic, social and religious development of the Belgian colony.

The world exhibition of 1958 in Brussels continued this tradition. Once again an indigenous village was erected and the colonial realisations were highlighted in the Congolese pavilion. 600 Congolese participated in the World Exhibition. Amongst them were Patrice Lumumba and Joseph-Désiré Mobutu. In Brussels they and other black intellectuals were for the very first time treated on an equal footing with whites. Ironically, the mutual contacts between the young black elite in Brussels provided a decisive impetus to the yearning for independence of the Congolese.

At the end of the fifties the process of decolonization gained unstoppable momentum. In 1959 riots broke out. The Belgian political establishment capitulated with speed and granted the Congo its independence. On 30 June 1960 the colonial period came to an abrupt end. Shortly after the independence celebrations heavy rioting erupted which forced a large number of Belgians to leave the former colony. In 1965 after five years of instability Mobutu Sese Seko came to power in a coup. His despotic rule, which lasted until 1997 when Laurent Kabila overthrew him, would bring the Congo to the brink of the economic abyss. During the last three decades a number of violent upheavals, armed conflicts and bouts of civil war have driven more and more Belgians back to Europe. Currently there is only a minimal Belgian presence in the Congo. 


\section{From a colonial perspective}

\section{Unilateralism}

The western world, and of course also Belgium and Flanders, was utterly convinced of the superiority of western civilization. It was the burden of the white man to bring Christian civilization to the Dark Continent. In his essay Het koloniale in de literatuur (The colonial in literature) written by De Jonghe in 1938 the author defined the concept "colonial" as follows:

The colonial is everything related to the Colony, to the profit region, which is exploited by a more advanced and more civilised country, in order to civilise the colony and to uplift the population. Indeed, civilization seems to be the first objective of colonization. Civilizing means the creation of a new and better social environment and the spreading of the greatest of all benefactions: spirituality and Christianity [...] (De Jonghe 1938: 7). ${ }^{2}$

De Jonghe seemed to be blind to the fact that the terms "exploitation" and "civilization" make strange bedfellows. This type of convoluted and contradictory reasoning is typical of a large number of pro-colonial texts. The argumentation in favour of the Congolese colony is nearly always riddled with inconsistencies and misrepresentations if not blatantly hypocritical or downright misleading. Ambiguities and contradictions characterise the literary works written by the authors who support the colonization effort. A large majority of literary texts on the Congo is fully in line with traditional Eurocentric thinking. In Flemish literature on the Congo, Western civilization reigns supreme. These literary works were published in Flanders and exclusively aimed at the home front. They confirmed and hence reinforced the commonly held Eurocentric convictions of their Flemish readership.

Myopic Eurocentrism inevitably led to the myth of a civilizing colonization. Despite the fact that Leopold II was forced to hand over his private property to the Belgian state after the disclosure of the unacceptable brutality of his colonial regime, the song of praise for the mammoth civilization task resounded vociferously throughout the whole colonial period. Flemish writers seemed to be suffering from collective amnesia regarding this unsavoury episode in their country's past.

\section{Writing as a hobby}

In the period before Congolese independence Flemish literature on the Congo was not of a very high literary quality. Most authors dabbled in literature in their leisure time. They are not professional writers and do not have serious literary ambitions. Ook een ideaal (Also an ideal) by Pieter Danco, published in 1896, was the very first Flemish novel written by an author who had stayed in the Congo where he was a civil servant. The Congo only features as an exotic backdrop to the sentimental and convoluted love affair between Helene and Hugo, a railway engineer. The reader is 
not allowed to lose sight of the fact that the main reason for the presence of the Europeans in Africa is to bring the fruits of western civilization to the Dark Continent. The building of the railway line between Boma and Stanley Pool, which connects the navigable part of the Congo River to the ocean, is the most important symbol of this task. But in their single-minded eagerness to carry out their idealistic mission the blacks are all but ignored by the whites. When the Senegalese railway workers revolt against their treatment and launch a violent attack on the whites, they are described as razende diere (raging animals) (Danco, 1896: 70). The attackers are beaten off with no regard for limb or life. This assault is not more than a minor incident, which momentarily enlivens the plot but is quickly forgotten.

Self-sacrifice is one of the main themes in the novel. However, the concept is only applied to the personal relationships between the white characters and thus becomes an exclusive for-whites-only label. As early as 1877 a booklet by A.-C. Van der Cruyssen Afrika, naar de beste bronnen (Africa on the basis of the best sources) was published. The author concludes his description with the following climactic appeal: "Yes, it will become a general crusade, not anymore with the sword in hand, but with words of peace and conviction, with feelings of love in the heart, with self-sacrifice in the soul!" (Van der Cruyssen 1877: 144). ${ }^{3}$ Ook een ideal by Pieter Danco vividly illustrates the restricted applicability of this ideal in the Congo: the whites are only prepared to make sacrifices for other whites, not for the blacks. Thus from the very beginning the mission to civilise the Congolese peoples was strictly delineated.

In 1961 Kongo ya lobi (The Congo of yesterday) was published. It contained a selection of short stories that had appeared earlier in the journal Bond (1942-1963). Bond was a general periodical about Flemish cultural activities in the Congo. The collection offered a sampling of Flemish literature on the Congo. The colonial mentality is dominantly present. Remarkable too is the ambiguous attitude towards black culture and society. In a number of stories black culture is presented as primitive and cruel. Only by adopting western civilization can there be any improvement in the lives of the blacks. However, when the black man, blinded by the glitter of urban life and the way of living of the whites, leaves his village to go to the city or even to travel to Belgium he always comes off second best. The message is unequivocally clear: happiness, love and tranquillity can only be found in the black village community. The upliftment of the black man is tolerated up to a certain limit; it may in no way threaten the existing hierarchical order and thus the dominant position of the white colonial rulers. Most works of prose that were published during the colonial period made that crystal clear. 


\section{Colonialist-critical prose}

\section{An ideal without any lustre}

While the bulk of Flemish-African literature supported and promoted the official policy of the civil and religious authorities, there was, throughout the colonial period, also a surprisingly vocal colonial-critical undercurrent that undermined the premises on which colonialism is built. This dissent had two, substantially different, forms of expression. On the one hand a number of literary works criticised the colonization of the Congo without demolishing the foundations on which the colonial constructs were built. The objective of the colonization was not questioned, only the way in which the colonizers were trying to achieve it. The writers concerned could fully identify with the main aim of the colonization. However, they had serious misgivings about the methods that were used.

Other writers, on the other hand, were much more extreme. They propagated an anti-colonialist point of view by rejecting the colonial enterprise out of hand. For them the white man had no right to interfere in Africa; the call to civilize Africa was just an empty slogan, which contrasted sharply with reality. The authors who followed this train of thought were not satisfied with policy changes. For them the colonization project itself was completely deluded and absurd.

To the first group belonged the authors who were missionaries. The missionaries were in the vanguard of the forces of colonization. They were from the outset aware of the necessity to know and understand African cultures and languages. They realized that without an intimate knowledge of black communities and languages their Christianization effort was doomed to failure. They studied the different African languages and cultures and were the first to render these languages into writing. Hence it is not surprising that blacks were the main characters in a number of literary works written by missionaries.

While Het zwarte leven van Mabumba (The black life of Mabumba, 1935) by A. Verreet still tells a very paternalistic story, empathy with the plight of the African characterizes the literary work of Alfons Walschap. The psychological portrayal of a black man, who in order to become a Christian has to relinquish his beliefs and traditions, forms the core of the short story "Longwanu de smid" (Longwanu the blacksmith). Ultimately Longwanu is converted to Christianity but the preceding conflict makes his conversion all the more nuanced and credible.

Some visitors from Belgium look at the Congo with open eyes. One of them is Jan Schoup. His novel Blanke boeien (White shackles, 1934) deals with conflicting white interests. The novel is a fierce indictment of the mining companies, of the local authorities and the Belgian government, who completely undermine the work of the missionaries. Despite his commitment Father Versteeg is engaged in an unequal battle, which he can but lose. His valiant efforts are to no avail and his work remains fruitless. He himself is killed. 
Another visitor was Gerard Walschap. After his return from a visit to the Congo in 1952 he writes Oproer in Kongo (Revolt in the Congo). The novel provides a cross section of colonial society with the rich plantation owner, the missionary and the black so called évolué, a black man who had attained a certain level of Western civilization, as the main characters. Each is given the opportunity of pleading his case. The black revolt is suppressed but the mutual relationships have irrevocably changed. The exploitation of the Congo by the plantation owner is denounced. He has to return to Belgium and is replaced by his son who believes in a new approach. Johannes, the évolué, is promoted to head of the workforce. With the rearrangement of the white-black relationship and the recognition of the humanity of the black person everybody is satisfied. That a different attitude towards the Congolese is urgently required, is the unequivocal signal that Walschap sends to the reader. The call for colonization with a human face does not fundamentally affect the power relationships and discourses in the colony.

The literary works discussed above were critical of the colonization and pleaded for a different approach that was based on the full acceptance of the black person as a human being while taking into consideration his cultural background and his identity.

\section{The myth demasked}

Apart from the criticism on the colonization by the civilization idealists, there was also, throughout the colonial period, an outspoken anti-colonialist trend. The first two Flemish literary texts on the Congo were two of Cyriel Buysse's satyrical Verslagen over den Gemeenteraad van Nevele (Minutes of the municipal council meetings of Nevele), dating from 1885. In De zwarte kost (Black grub), a novella published in 1898, Buysse returned both to the colonial theme and to the scathingly satirical treatment of his subject matter.

In De zwarte kost the whites are the targets of Buysse's fierce criticism, some because of their narrow-mindedness, hypocrisy, short-sightedness, bigotry and ignorance, others because of their naivety and megalomania. Western civilization is not worth its name. The whites are the real barbarians; they can offer the Congo nothing but misery and hardship. Buysse denounces the colonial propaganda, which plays on the exotic appeal of the Congo, the prospect of a life of adventure and the ideal of bringing Western civilization to a backward continent. The motives of the colonizers are unmasked: they are driven by self-glorification or base instincts and not at all by humanitarian concerns. At a time when the colonization effort was still in its infancy, Buysse already publicly declared its bankruptcy.

Buysse published his novella in 1898. In the same year Henri van Booven left for the Congo in the service of a Dutch trading company. The latter's novel Tropenwee (Tropical agony, 1904), which he wrote a few years later, vividly described the horrors 
awaiting the whites in central Africa. Tropenwee is the account of the trip undertaken by a certain Jules to the Congo. The closer he gets to the tropics and the more the heat intensifies, the more his unease and discomfort grow. As soon as he has landed in the Congo his chief sends him straight into the interior. On the boat on the Congo River he is weakened to such a degree by malaria and dysentery that he has to return to the Netherlands forthwith. He barely manages to survive his ordeal. The middle section of the novel consists of the hallucinatory nightmares the main character suffers from during bouts of malaria. The last part describes the hellish return trip. Only when Jules gets closer to the north, does he feel his energy and strength returning. Congo has brought him nothing but suffering.

Tropenwee is the description of a descent into hell. The writer paints an evocative and haunting picture of Jules' excruciating bouts of fever during his voyage on the Congo River. For Jules Africa is a threat. The heat, the insects and storms make his life unbearable. It is remarkable that in no way the presence of the white man in Africa is justified. Not a single word is mentioned about the civilizing mission. Only commercial interests motivate the presence of the Europeans in Africa. Once again the motives for the colonization are effectively punctured:

It was all deceit, all lies and chicanery. Could one have done something about it? To complain, to confront the supervisor? It would be to no avail. Then one would lose one's chance to be promoted. To work hard, to do one's duty, duty animal, duty bastard and to deceive for the benefit of the company and your own. In this way everything of value was destroyed. Nature itself withered, was just an obstacle and no more than that. And the blacks, they were black cattle who you had to treat harshly, rigidly and cruelly; you had to keep them under your thumb and make sure that they did not steal from you. With kind words? O, No! With bestial toughness and with lots of beatings. Yes, sure, ultimately you had to become a torturer, to beat your fellow human beings with dried out rhinoceros skin until they started bleeding, these hard long, dirty-yellow sticks with which you could hit so hard that whole muscle groups were torn apart [...] The shares stood a lot above par and there they should stay. You had sold yourself, so duty-animal, duty-scoundrel! Duty-torturer! And all the profit to the company! ... (Van Booven s.d.: 118-19). ${ }^{5}$

Tropenwee was a fierce indictment of the fact that the suffering, the diseases, the greed, the inhumanity and the deadly victims resulting from the exploitation of the tropics were swept under the carpet. As in Buysse's De zwarte kost the blacks figure only in the margins of the novel. They do not form a counterweight to the depravity of the whites. Van Booven does not describe the African or African society as an ideal. He focuses on the presence of the European in Africa. The white man is not adapted to Africa. Europe has nothing to offer to Africa apart from avarice and greed, Africa to Europe nothing but diseases and death. This sobering assessment leaves no room for 
colonial triumphalism and renders any alibi for colonial imperialism null and void. The novel was a popular success and was reprinted time and again.

René Poortmans picked up the anti-colonialist tread in the thirties. His novel Moeder ik sterf (Mother I am dying, 1937) is a frontal attack on the cruel exploitation of the blacks by the mining companies. The tropics affect the whites to such an extent that they lose all sense of morality. The words of the title "Mother, I am dying" are spoken by a black man and express the fate of the Congo. The novel expresses utter pessimism: "One drifts from Europe to a post; and from the suffocating post in the heat back to the dead, stone Europe. Lost on both sides" (Poortmans s.d.: 224). ${ }^{5}$

In 1959 De nikkers (The niggers) by Piet van Aken was published. In this novel the main character, Meersman, the administrator of a district, relates the events concerning a black strike. However, the strike itself becomes merely incidental. The whites are more concerned about protecting their own positions and privileges than about the strike and the frustrations of the black workforce. This shift in focus from the central incident to what is taking place on the periphery of the strike is an illustration of colonial policy itself: it too makes the situation of the blacks completely inferior to white interests. De nikkers posits that the colonial situation is one of misuse of power in which the ruler suppresses without mercy the weaker party. The white man is accused of being the rapist of Africa. Despite the fact that the novel ends in the confirmation of the status quo, it also subtly suggests that the present balance of power will not last for ever. The episode in which Cathérine, a woman of mixed blood, whom Meersman is in love with, spits on him as she sees him as the representative of the white power apparatus, illustrates the suppressed anger which will eventually erupt in a violent revolt.

In the literary works, which undermined the legitimacy of the colonization project the emphasis is on the nature of man itself. The white man had nothing to offer Africa. He was only motivated by self-interest and greed. As a result the colonization lost all moral basis and ethical foundation.

\section{The post colonial period}

\section{The trauma of the dipenda}

With the lowering of the Belgian flag on 30 June 1960 the colonial period came to an abrupt and unforeseen end. Flemish literature on the Congo underwent a drastic change. The rioting, which broke out after independence clearly made a big impression on writers. A number of fictional works dealt with this subject matter. Djiki-Djiki (1972) by Jan van den Weghe, Zonen van Cham (Sons of Cham, 1964) by A. Claeys, De rode aarde die aan onze harten kleeft (The red earth which clings to our hearts, 1962) by Daisy Ver Boven and Ik blanke kaffer (I, white kaffir, 1970) by Paul Brondeel are just a selection of titles which were inspired by the violent upheavals or use them as a 
backdrop. Most authors were eyewitnesses who were caught up in the violence themselves. In their novels the blacks are drawn in a very negative light while the whites are seen as the innocent and defenceless victims of raw racial hatred.

The novel Zonen van Cham by André Claeys is situated at the time of the independence. Van der Smissen is the new head of the prison in Dembele. He treats the prisoners as a caring father; he is appreciated by them and by his subordinates. The childishness and naivety of the blacks sharply contrast with the wisdom and benevolence of the white man. No wonder that the white characters are of the opinion that independence is granted much too early. The terrible incidents, which occur after the independence celebrations seem to indicate that they are right. Van der Smissen has to flee. During his flight he and his family are cornered. Van der Smissen shoots his wife rather than have her fall into the hands of a vicious black mob. He is killed by the mob. To add insult to injury the worst atrocities are committed by the so-called évolués.

\section{The clash of cultures}

The violence, which marred the period immediately after independence, squarely confronted the white man with the dismal failure of the colonization, civilization and Christianization project. This led to a great deal of soul searching. The universality of western values was examined and the problems regarding acculturation were highlighted. The problematic relationship between whites and blacks was often symbolised in an interracial love relationship. Novels such as Albert van Hoeck's Over de grens (Across the border, 1970), Daisy Ver Boven's Mayana (1974), Raf van de Linde's De Moeloeba Catteeuw (The Muluba Catteeuw, 1965) and Jan van den Weghe's novella Offerhonden van stro (Sacrificial dogs made from straw, 1965) dealt with this subject matter. In these novels the impossibility to establish a permanent loving relationship illustrates an unbridgeable cultural gap between black and white.

In the évolué the clash between African and western culture was most acutely expressed. In Ik ben maar een neger (I'm just a nigger, 1962) and Het verhaal van Matsombo (The story of Matsombo, 1966) by Jef Geeraerts the évolué Matsombo, an opportunist without a moral compass, is the main character. The bankruptcy, both of western civilization and of black culture, are expressed in no uncertain terms by Matsombo. His depiction perfectly fits into Jef Geeraerts' romantic view of the world. In Geeraerts' eyes western society is depraved. Africa conjures up a paradisiacal prehistoric world: "And that is why he ridicules the black évolué. Not because he is black but because he wants to be white. In order to do so, he has to abandon the blissful primary state of thoughtlessness. Every évolué is, in the eyes of Geeraerts, one too many." (Anbeek 1995: 85) ${ }^{6}$

A more authentic representation of the African and of African society can be found in the literary works written by Jac. Bergeyck. From 1947 to 1959 Bergeyck was a missionary in the Congo. He was intrigued by the traditions and the culture of the 
blacks. His anthropological interest and research was directly transferred to his literary work which consists mainly of novels. His novella Het onzekere hart (The uncertain heart) was publihed in 1959. It was followed by De levende doden (The living dead, 1960), Het levende beeld (The living statue, 1962), Het stigma (The stigma, 1970), De pofadders (The puffadders, 1975), Een tuin die niet van Eden was (A garden which was not from Eden, 1985) and Het orakel (The oracle, 1987). The most striking characteristic in his work is the empathy with the African. Bergeyck excels in situating the black man within his cultural traditions. He pays little or no attention to political or social developments.

In the period immediately after independence quite a large number of literary works were published. The bankruptcy of the civilization project was frankly acknowledged. To some writers this demonstrated once again the inferiority of the black man, yet for a writer such as Bergeyck the dipenda (independence) provided the opportunity for the black man to throw off the yoke of western civilization and to become the master of his own fortune and future. After the rioting, which followed the independence celebrations the Belgians left the Congo in droves. In Belgium they wrote down their experiences. Consequently most Flemish literature on the Congo is retrospective in nature: the ex-colonial looks with nostalgia, puzzlement or embitterment back on a period that is closed off for good.

\section{Congo revisited}

The missionary Guido Tireliren went to the Congo some time after the independence troubles. He wrote three novels about the Congo: Uit stenen geboren (Born from stones, 1979), Levende stenen (Living stones, 1982) and Aiwa's tocht (Aiwa's trip, 1984). In his novels he discusses the problems of post-independence Congo. Guido Tireliren explores the precarious situation of the African who continually has to choose between old and new, between the traditional way of living and modernity. The evolution to a modern society cannot be stopped. The old structures are crumbling and have to be replaced. Tireliren posits, as can be expected of a missionary, that Christian values and education have to be the corner stones of a new society. Tireliren's novels end optimistically: his main characters are prepared to adapt to a new environment. For this reason the hope in the future is warranted. Tireliren has abandoned western paternalism in order to demonstrate the need for change and development from a black perspective.

The Flemish presence in the Congo has been further reduced after a number of outbreaks of rioting during the last decades. In terms of the literary work this means that the travel narrative makes a comeback: a curious but uninvolved outsider observes, describes and vents his opinion; the brave adventurer, the idealistic pioneer or missionary has been replaced by the sceptical realist. 
Lieve Joris is a writer of travel narratives and fiction. She has close ties with the Congo: her uncle was a missionary there. In her book Terug naar Kongo (Back to the Congo, 1987) she describes a visit to the Congo in the footsteps of her uncle. In her books on the Congo Joris explores contemporary Congolese society. She describes and tries to understand:

In that sense I am of the opinion that the post-colonial generation has a duty, the duty to show how different things are now. I went looking for Congolese intellectuals. Because I wanted to know how they think about their country and how they look upon their youth. I wanted to find out what we as whites had meant there [...] I think we are the first generation, which can look at it in an undetached way (in De Moor 1987). ${ }^{8}$

Joris knows that she depicts the Congo through western eyes but precisely this awareness and her stubborn attempts to dig beneath the surface allow her to explore the complexities of the Congo. Her trip was not only an expedition through the present but also through the past. It traced Belgium's relationship with the Congo. This led to a multifaceted picture of a complex interaction in which the black person is emphatically present. Terug naar Kongo is a fascinating travel narrative, which throws a new light upon a familiar subject matter. The travel narratives Dans van de luipaard (Dance of the leopard, 2001) and De hoogvlaktes (The plateaus, 2008), and the novel Het uur van de rebellen (The hour of the rebels, 2006) are testimony of Lieve Joris's continuing fascination with the Congo.

In the novel with the telling title Afrika retour (Return trip to Africa, 1993) by Markus Leroy, the optimism of Tireliren and the realism of Joris are replaced by cynicism. The main character is the head of the Belgian department for development cooperation in an African country, which can easily be recognised as the Congo. The corruption of the Congolese government and the political interference in the Belgian department of development cooperation mean that effective aid cannot be provided. Only a cynical attitude allows the main character to survive in such an immoral environment. Afrika retour is a scathing novel in which there is no room for postcolonial guilt and remorse.

\section{Not in the same boat}

Most Flemish writers of travel narratives and fiction on the Congo have not been able to shed their cultural background and ideological baggage, with the result that the picture they sketch of the African and of the Congo is just a reflection of their own attitudes and mentality. Obviously these types of literary works do no lead to a better insight into the Congo and a better understanding of the Congolese. Literary works written in this vein have not played a pioneering role but have expressed the preva- 
lent colonial mentality and as such have contributed to its dissemination and widespread acceptance in Flanders during the colonial period.

Nevertheless there are also a number of writers who comment critically on the colonial project. In a small body of literary works an attempt is made to come to a better understanding of the world of the black man, his traditions and his culture. Occasionally, the white presence in the Congo is critically examined or the illusion that the Congo is the new Eden is radically undermined. A small number of literary works can, to a lesser or a larger degree, even be characterised as attacks on the ideology of colonialism. Both for its literary value and for its openness critical, colonial prose has made and is still making an important contribution to Flemish literature.

\section{Notes}

1 "... het onderdrukken van de slavenhandel in Centraal-Afrika, het vergroten van de wetenschappelijke kennis van het gebied en het brengen van beschaving naar de daar woonachtige volkeren" (Foeken 1985: 19-20).

2 "Het koloniale is dat wat betrekking heeft tot de Kolonie, tot het wingewest, dat uitgebaat wordt door een meer gevorderd en meer beschaafd land, om door dit uitbaten die kolonie te beschaven en de bevolking op te beuren. Want, beschaving lijkt wel het eerste doel der kolonisatie. Beschaven heet scheppen van nieuwe en betere sociale toestanden en het verspreiden der grootste aller weldaden: de geestelijke orde, de kristelijke idée [...]" (De Jonghe 1938: 7).

3 "Ja, het zal een algemeene kruistocht worden, niet meer met het zwaard in de hand, maar met woorden van vrede en overtuiging, met liefdegevoelens in het hart, met zelfopoffering in de ziel!" (Van der Cruyssen 1877: 144).

4 "Het was alles bedriegerij, alles leugen en bedrog. Was er iets aan te doen geweest? Opspelen, standjes maken bij den hoofd-inspecteur? Dat gaf niets. Dat kon alleen kans geven op weinig promotie. Hard werken maar en plicht doen, plicht-dier, plichtschoft zijn en mee bedriegen ten bate van de vennootschap en ten eigen bate. Op die manier ging alle moois weg. De natuur werd er zelfs dor van, hinderlijk alleen nog maar, meer dan hinderlijk. En de zwarten, dat was het zwarte vee waartegen je hard moest zijn, stug, wreed; die moest je onder den duim houden, zorgen, dat ze je niet bestalen. Met goede woorden? O! Neen! Met beestachtige hardheid en met veel ransel. Ja, zeker, beul moest je ten slotte ook nog worden, je medemenschen ten-bloede slaan met gedroogde nijlpaardenhuid, van die harde, lange, vuil-gele stokken waarmee je een slag geven kon, die heele spierbundels stuk rukte .... De aandeelen stonden ver boven pari, en boven pari zouden ze blijven. Je had je verkocht, dus plicht-dier, plicht-schurk! Plicht-beul! En alle winsten voor de Vennootschap! ..." (Poortman s.d: 224).

5 "Men zwerft van Europa naar een post; en van den dooden post in de hitte naar het doode, steenen Europa. Verloren aan beide kanten." (Van Booven s.d.: 118-19).

6 "En juist daarom maakt hij de zwarte évolué belachelijk. Niet omdat hij zwart is, maar omdat hij wit wil zijn. Daarmee dwaalt hij af van de gelukzalige oerstaat van gedachteloosheid. Iedere évolué is er in Geeraerts' ogen één teveel." (Anbeeck 1995: 85).

7 "In die zin vind ik dat de postkoloniale generatie een plicht heeft; de plicht om te laten zien hoe anders het nu is. Ik ben op zoek gegaan naar Zaïrese intellectuelen. Want ik wou weten hoe zij denken over hun land en hoe zij op hun jeugd terugkijken. Ik wou weten wat wij daar als blanken betekend hebben [...] Ik denk dat wij de eerste generatie zijn die onbevangen kan kijken." (Joris in De Moor 1987).

\section{Works cited}

Anbeek, T. 1995. Het donkere hart. Walschap, Geeraerts en de Kongo. Ons Erfdeel, 38 (1): 75-87.

Bergeyck J. 1959. Het onzekere hart. Leuven: De Clauwaert. 1960. De levende doden. Antwerpen: De Standaard. 
1962. Het levende beeld. Antwepen: De Standaard.

1970. Het stigma. Leuven: Davidsfonds.

1975. De pofadders. Brussel: De Arbeiderspers.

1985. Een tuin die niet van Eden was. Leuven: Davidsfonds.

1987. Het orakel. Leuven: Davidsfonds.

Boelaert, E. 1938. Poortmans R. Moeder ik sterf. Boekengids, 16 (1): 29.

Bogers, K. en Wymeersch, P. 1987. De Kongo in de Vlaamse fiktie- en reisverhalen. Brussel: Asdoc studies 4 5.

Brondeel, P. 1970. Ik blanke kaffer. Antwerpen: Standaard Uitgeverij.

Buysse, C. 1974a. Verzameld werk deel 4. Samengesteld en ingeleid door A. van Elslander en A.M. Musschoot. Brussel: Manteau.

.1974b. Verzameld werk deel 7. Samengesteld en ingeleid door A. van Elslander en A.M. Musschoot. Brussel: Manteau.

Claeys, A. 1964. Zonen van Cham. Leuven: De Clauwaert.

Claeys, Herman J. 1966. Een mens van slechte wil. De groene Amsterdammer. 29.01.1966.

Danco, P. 1896. Ook een ideaal. Gent: Drukkerij A. Siffer.

De Deken, C. 1952. Twee jaar in Congo. Antwerpen: De Vlijt.

De Jonghe, S. 1933. Tam-tam. Tropennovellen. Herstal: Uitgave Zaïre. . 1938. Het koloniale in de literatuur. Turnhout: Van Mierlo-Proost.

De Moor, P. 1987. Terug naar Kongo van Heeroom. HN Magazine, 25 april.

De Sterck, M. 1985a. Jac. Bergeyck. Boekengids, 63 (3): april, back cover. 1985b. Kongoromans met stevig stigma. Kerk en leven, 8, 21 februari, 14.

Foeken, D. 1985. "België behoeft een kolonie". De ontstaansgeschiedenis van Kongo-Vrijstaat. Antwerpen, Amsterdam: De Vries, Brouwers.

Geeraerts, J. 1990. Ik ben maar een neger. Het verhaal van Matsombo. Antwerpen, Amsterdam: Manteau.

Janssen, Em. 1961. Kongo ya Lobi. Leuven: Davidsfonds.

Joris, L. 1986. De golf. Amsterdam, Antwerpen: Veen, uitgevers.

. 1987. Terug naar Kongo. Amsterdam, Leuven: Meulenhoff, Kritak.

1990. De melancholieke revolutie. Amsterdam, Leuven: Meulenhoff, Kritak.

1991. Een kamer in Cairo. Amsterdam, Leuven: Meulenhoff, Kritak.

1992. Zangeres op Zanzibar. Amsterdam: Meulenhoff.

1993. De poorten van Damascus. Amsterdam, Leuven: Meulenhoff, Kritak.

2001. Dans van de luipaard. Amsterdam: Meulenhoff.

2006. Het uur van de rebellen. Amsterdam: Uitgeverij Augustus.

2008. De hoogvlaktes. Uitgeverij Augustus: Amsterdam.

Kerels, L. 1947. Tropenleven. Bond, 6: 421-27.

Leroy, M. 1993. Afrika retour. Leuven: Davidsfonds.

Luwel, M. 1952. De Limburgers in Kongo. Hasselt: K.M. De Koloniale Dagen van Limburg.

Maes, A. 1879. Reis naar Midden-Afrika. Leuven: Peeters-Ruelens.

Poortmans, R. s.d. Moeder ik sterf. Antwerpen: Belgische Uitgeversmaatschappij.

Renders, L. 1994. Limburgse auteurs in Afrika. In Acta van het Colloquium Limburg 1945-1992. Diepenbeek: LIWAG, 117-30.

1997. Cyriel Buysse, an early anti-colonialist. Dutch Crossing, 21 (1): 87-101.

. 1998. Van Kongo naar Zaïre: Lieve Joris in het hart van Afrika. In Leijnse, E. en Van Kempen,

M. Tussenfiguren. Schrijuers tussen de culturen. Amsterdam: Het Spinhuis.

. 1998. De Congo-Vrijstaat op de korrel. In T. D'Haen en G. Termorshuizen (reds.). De geest van

Multatuli. Leiden: Vakgroep Talen en Culturen van Zuid-Oost Azië en Oceanië, 214-32.

2002. Nikkerke en ikkerke. Nederlandstalig proza over Kongo. In T. D'Haen (red). Europa

buitengaats. Deel 1. Amsterdam: Bert Bakker, 302-58.

2004. De kloof tussen ideaal en realiteit. In M. van Kempen, P. Verkruijsse, en A. Zuiderweg.

Wandelaar onder de palmen. Opstellen over koloniale en postkoloniale literatuur. Leiden: KITLV.

. 2005. Romantiek in Kongo: blanke mannen en zwarte vrouwen. In A. Oliphant, en H. Roos.

Word, (Wo)man, World. Essays on Literature. Pretoria: Unisa Press, 230-44. 
Rotenstreich, H. 1986. Reisjournaliste Lieve Joris: "ik heb het gezien en dat zeg ik ook". De journalistieke verbeelding. In P. Hagen, L. Van Schaardenburg en A. Truijens (reds). Untrecht, Antwerpen: Veen uitgevers.

Schoup, J. 1937. Blanke boeien. Velsen: Schuyt.

Tilemans, E. 1931. Bendsjé. Brussel: A. Lambrechts.

Tireliren, G. 1979. Uit stenen geboren. Tielt, Amsterdam: Lannoo. 1982. Levende stenen. Leuven: De Clauwaert. 1984. Aiwa's tocht. Leuven: De Clauwaert.

Tollet, M. s.d. Contractnegers. Leuven: Davidsfonds.

Van Aken, P. 1959. De nikkers. Antwerpen: Ontwikkeling.

Van Booven, H. s.d. Tropenwee. Amsterdam: Maatschappij voor goede en goedkoopelectuur. H. 1901. Witte nachten. Haarlem: Gebr. Nobels.

Van den Weghe, J. 1965a. Kinderen van Kongo. Brussel, Den Haag: Manteau. 1965b. Liefde en avontuur in Midden Afrika. Antwerpen: De Standaard. 1972. Djiki-Djiki. Brecht: De Roerdomp.

Van de Linde, R. 1963. Die tijd is nu voorbij. Leuven: De Clauwaert. 1965. De Moeloeba Catteeuw. Leuven: De Clauwaert.

Van der Cruyssen, A.-C. 1877. Afrika, naar de beste bronnen. Kortrijk: Ch. Vandesteene.

Van Hoeck, A. 1968. De miskraam van moedertje Dipenda. Leuven: Reinaert-uitgaven. 1970. Over de grens. Brussel: Reinaert. 1989. Ontstaan van de post-koloniale roman in 1959-1970. Vlaanderen, 38 (2): 82-89.

Van Straelen C. 1947. Wegwijzer voo wie naar Kongo wil. Antwerpen: Standaard-Boekhandel.

Ver Boven, D. 1962 De rode aarde die aan onze harten kleeft. Brussel: Reinaert. 1974. Mayana. Leuven: De Clauwaert.

Vermeulen A. s.d. De pioniersdagen van Chicongo. Antwerpen: De Sikkel.

Vermeulen, J. 1988. De Centraalafrikaanse woordkunst en de Nederlandse Afrika-literatuur. Gent: Rijksuniversiteit Africana Gandensia 5.

Verreet, A. 1935. Het zwarte leven van Mabumba. s.l.: Davidsfonds.

Verthé, A. 1959. Vlamingen in Kongo. Leuven: Davidsfonds. . en Henry, B. 1961. Geschiedenis van de Vlaams-Afrikaanse letterkunde. Leuven: Davidsfonds.

Vints, L. 1984. Kongo made in Belgium. Leuven: Kritak.

Vlaanderen, 38 (2), maart-april, 1989. (Themanummer over de Afrika-roman in Vlaanderen.)

Walschap, A. 1952. Het letterkundig werk van Alfons Walschap. Ingeleid door V. Celen. Antwerpen: De Sikkel.

Walschap, G. 1965. Opdat de blanke ontwake. Nieuw Vlaams Tijdschrift, 18 (11): 907-08. 1980. Oproer in Kongo. Antwerpen: Beckers. 